\title{
Dmitry Uzlaner Epilogue: Reflections on Globalizing Culture Wars
}

Culture war is a concept that was used by James Davison Hunter in order to describe the bitter conflict in the US between "orthodox" and "progressive" over which moral vision is correct and should become the foundation of human society. "Orthodox" actors - one can also call them conservatives or traditionalists - adhere to the idea that key human institutions are rooted in transcendent principles and cannot be changed by circumstances or human will, while "progressives" - one can also call them liberals - believe that all institutions develop historically and in new contexts can be conscientiously changed. ${ }^{2}$ The mobilization of religious conservatives (the Christian Right) - who are the focus of this volume and the Postsecular Conflicts research project project behind it - was a reaction to the advancement of the progressive agenda, which, in the opinion of traditionalists, undermined the moral foundations of society, for example, by questioning traditional notions of gender and authority. Culture wars have been embodied in a series of highly emotional confrontations over such issues as abortion,

1 See James Davison Hunter, Culture Wars: The Struggle to Control the Family, Art, Education, Law, and Politics in America (New York: Basic Books, 1992).

2 Ibid., 44. 
religion at school, homosexuality, pornography, contemporary art, etc. ${ }^{3}$

Hunter's work was devoted to the processes in American society, but in general, similar conflicts have affected any society that was influenced by the "cultural revolution" of the 1960s and the social dislocations that followed. As Kristina Stoeckl rightly put it in the introduction, culture war is not the only form that these kinds of postsecular conflicts take. Culture war seems to be pretty much an American phenomenon, while the European context, for example, is better described through the concepts of postsecular society and the postsecular search for consensus (along the lines of Jürgen Habermas's thought). ${ }^{4}$

To a certain extent, it can be argued that these kinds of conflicts have replaced the ideological confrontation of the Cold War and the "end of history" phase, which, as some believed, started as soon as the great battle between Communists and capitalists was over. It can hardly be argued that the confrontation between traditionalists and progressives over abortion or LGBTQ+ rights is comparable in scope and intensity to the confrontation of the Cold War. However, it is undoubtedly one of several key contemporary conflicts along with, for example, the confrontation with global terrorism.

In recent decades we have observed a very peculiar transformation: the culture war between conservatives and liberals, which was initially limited to American borders, began to take on a transnational and global dimension. ${ }^{5}$ This process started as early as the late 1980s and its visible manifestations are the emergence of transnational alliances of conservatives and the export of the traditionalist worldview to regions and continents that have not yet been fully seized by the dynamics of the American culture wars. ${ }^{6}$ Culture wars are globalizing - not only in the sense

$3 \quad$ Ibid. 3

4 Jürgen Habermas, "Notes on Post-Secular Society," New Perspectives Quarterly 25, no. 4 (2008): 17-29.

5 For more, see Clifford Bob, The Global Right Wing and the Clash of World Politics (Cambridge: Cambridge University Press, 2012).

6 James T. Gathii, "Exporting Culture Wars," U. C. Davis Journal of International Law \& Policy 13, no. 1 (2006): 67-93; Peter Berger, "Exporting the American Culture War," The American Interest, 20 August 2014, https://www.the-american-interest.com/2014/08/20/ exporting-the-american-culture-war/. The same, of course, could be said about the opposite - "progressive" or liberal - camp. However, the focus of this volume is on the conservative position. 
that conflicts over values are becoming visible all over the world and even in international institutions like the $\mathrm{UN}^{7}$ (this is just one aspect of this globalization), but also in the sense that these conflicts more often than not take the form of a culture war, a fierce polarization where any consensus is almost impossible.

There are several key actors representing the traditionalist position in this new globalized context - these actors are joining their efforts in a kind of ecumenism 2.0. ${ }^{8}$ One of these, of course, is the Vatican, which was one of the first to engage in this type of confrontation during the pontificates of Pope Paul VI and Pope John Paul II. ${ }^{9}$ Some Muslim actors, particularly the Organization of Islamic Cooperation, which has tried to be active in the UN and to interact with like-minded partners from other religions, also subscribe to the traditionalist position. ${ }^{10}$ However, the key actor for our research is the American Christian Right, a movement forged during the American culture wars of the 1970s and 1980s. ${ }^{11}$ The Christian Right became the key drivers of this globalization of culture wars and the formation of transnational alliances of conservatives. ${ }^{12}$ Another important actor is Russia, which is a latecomer, becoming a significant player on the conservative side only in the second decade of the 21st century: in 2012 the Russian regime, backed by the Russian Orthodox Church, started - quite successfully I should say - to position itself

$7 \quad$ Katherine Marshall, "Engaging on Global Issues in a UN Setting: Religious Actors," in Religion, State and the United Nations: Value Politics, ed. Anna Stensvold (New York: Routledge, 2017), 17-26.

8 On this concept, see Andrey Shishkov, "Two Ecumenisms: Conservative Christian Alliances as a New Form of Ecumenical Cooperation," State, Religion and Church 4, no. 2 (2017): 58-87.

9 A good treatment of this is the recent book by Frederick Martel, which not only describes the chronology of this struggle, but also shows its consequences for the Catholic Church (Frederic Martel, In the Closet of the Vatican: Power, Homosexuality, Hypocrisy [London: Bloomsbury Continuum, 2019]).

10 See, in particular: Marie Juul Petersen and Heini Skorini, "Hate Speech and Holy Prophets: Tracing the OIC's Strategies to Protect Religion," in Religion, State and the United Nations: Value Politics, ed. Anna Stensvold (New York: Routledge, 2017), 44-61.

11 See Seth Dowland, Family Values and the Rise of the Christian Right (Philadelphia: University of Pennsylvania Press, 2015).

12 Jennifer Butler, Born Again: The Christian Right Globalized (Ann Arbor, MI: Pluto Press, 2006). 
as the last bastion of traditional values and the leader of the global conservative front. ${ }^{13}$

This volume brought together conversations with some of the key representatives of contemporary "culture war conservatism" both from the US and Russia. These conversations were balanced by voices that offered a critical look at this ideology. These materials show how contemporary traditionalists evaluate the dynamics of culture wars, whether they agree with the widespread thesis that conservatives have lost the culture war, how US conservatives perceive Russian conservatives and vice versa, and whether these alliances against transnational liberalism are stable and enduring. Finally, the materials show the conservative attitude toward Europe, which - against the backdrop of the rise of populist movements has become a zone of special interest for the strategists and commanders of the culture wars. This last issue is especially relevant in the context of the question posed by Kristina Stoeckl in the introduction: if the culture wars are brought to Europe and if Europe is seen as a mission field by culture warriors, then the European model of a postsecular society oriented toward consensus is under threat and in danger of being replaced by the globalizing model of the American culture war.

In what follows I will share my reflections and observations concerning the current state of global culture wars on the basis of the materials published in this volume.

Increasing polarization and disappearance of the center. The theme that cuts across the volume is the disappearance not only of some kind of consensus, but also of a dimension where meaningful rational exchange of arguments is possible. ${ }^{14}$ These conditions are already implied in the very concept of culture war, but, as our interlocutors see it, the situation is becoming much worse. R. R. Reno points out that the general background of the Cold War pushed both conservatives and progressives not only toward a centrist position, but also toward the formation of a certain consensual positions: yes, changes are necessary, but - conservatives asserted - these changes should not be too fast and too rapid. How-

13 See Kristina Stoeckl, "Postsecular Conflicts and the Global Struggle for Traditional Values" (lecture), State, Religion and Church 3, no. 2 (2016): 102-16.

This was emphasized by Clifford Bob in The Global Right Wing. 
ever, the end of the Cold War "made the cultural consensus of the Cold War era, built around [...] 'diversity over unity' and 'openness over closure' both more powerful and more dysfunctional” (p.55). The checks and balances that allowed centrist positions to exist and prevented excessive polarization with the inevitable radicalization of the parties have disappeared. The image that is often mentioned in descriptions of the current stage of culture war is that of a "civil war," the most extreme phase of civil confrontation. As Rod Dreher, for example, puts it: "when I look at the US now, I think about Spain in 1931, when the trouble started there that eventually led to a civil war. I don't think that we will pull guns against each other in the US, but the polarization is so great now and there's no center left" (p. 28). ${ }^{15}$

The image of violent confrontation over values and identities, which in the American context sounds like a warning, like a kind of exaggerated description of the intensity of ongoing polarization, in the Russian Orthodox context takes a much more sinister turn. Alexander Filonenko, philosopher, theologian, and member of the Ukrainian Orthodox Church Moscow Patriarchate, reflects on the conservatism of traditional values and evaluates it against the background of the ongoing military conflict between Russia and Ukraine. This conflict has a clear value dimension - at least from the Russian side it is often portrayed as a reaction to the attempt of the liberal West to subvert the "Russian world," which is based on adherence to traditional values and a traditional way of life. Filonenko points to the growing cleavage between adherents of traditional values and those members of the Eastern Orthodox Church who don't share this ideological vision. This cleavage is visible all over the Eastern Orthodox world. What is really troubling is the fact that these two groups - at least, in Ukraine - can no longer talk to each other and stop perceiving each other as parts of a single Orthodox community. These value conflicts are the context "from which demons are born" (p. 76) - demons of war and demons that divide the Church, members of which live both in Rus-

15 In the early 1990s James Davison Hunter paid attention to this sinister dimension of evolving value conflicts. In Before the Shooting Begins: Searching for Democracy in America's Culture War (New York: Free Press, 1994), he described how discussion degenerates into a caricaturish battle dangerously charged with intense emotions. 
sia and Ukraine. Ideological confrontation, the struggle over values and identities exacerbated by the uneasy territorial relations between Russia and Ukraine, has split the common space of Russian Orthodoxy. The Russian-Ukrainian context that Filonenko is talking about is, of course, very specific and cannot be reduced solely to confrontation around different understandings of moral vision. However, it shows how easily confrontation over values and identities develops into a military struggle that threatens to destroy community. The tensions around the "Russian World" " 16 reveal in a much more dramatic and violent form the polarization and loss of any consensus that American participants and observers of culture wars are talking about.

The eclipse of the mind and the rise of emotions. Positions on the opposing sides in these conflicts appear to be embedded in large emotionally charged narratives that nearly bring the work of reason to a standstill. Certain issues in these struggles, for example, confrontations about the definition of family or non-discrimination against LGBTQ+ people, are not technical issues waiting to be resolved pragmatically. These are symbols that, like any other symbols, point to something beyond - to comprehensive narratives about the war between good and evil, light and darkness. This vision of something like a "cosmic war" makes it impossible for each side to hear the other's positions and turns the very debate into a small part of a bigger story. Progressive, liberal actors adhere to the narrative of gradual progress and the emancipation of the human person from various limiting forces and prejudices, while the conservative side sees the culture war as the history of a transcendentally founded order that is about to collapse under the pressure of human sin and immorality. conservatives are not fighting same-sex marriages or abortions as such, these are just symbols of the moral order, of the hierarchies that might collapse at any moment, plunging society into the chaos of non-differentiation, where everything becomes mixed - high and low, bad and good, old and young, male and female, parents and children. ${ }^{17}$ Or alternatively Influence,"' Geopolitics 23, no. 2 (2018): 330-53.

For more on this, see Dmitry Uzlaner, "The Logic of Scapegoating in Contemporary 
they envision a world gripped by a new totalitarianism, where everything would be turned upside down - evil would take the place of good, low in the place of high, etc. The US Supreme Court has legalized same-sex marriages and the world has not collapsed. But this is not a reason to give up the fight, because it is not a fight for or against same-sex marriage, it is a fight against chaos, against immersion in disorder, or the inverted order of the new 1984. Such narratives, imbued with emotions - fear, anxiety, righteous indignation - lead to a black-and-white perception of the world, to the demonization of the opponent and to the impossibility of achieving even some minimal consensus. ${ }^{18}$

Russia and the United States as screens for each other's projections. Russia and the US are once again becoming screens for each other, on which corresponding actors project some of their own images arising from the internal logic of corresponding societies. ${ }^{19}$ The transformation, the inversion of each other's images that has taken place since the Cold War, is remarkable. During the Cold War, the USSR (Russia is the successor to the USSR) was perceived by American conservatives as an "evil empire," as a source of destructive cultural influences (let's remember the fake "Communist Rules for Revolution" ${ }^{20}$ ), while the US was perceived as a force that was preventing the world from the final triumph of godless Communism and anarchy. The USSR, by contrast, positioned

Russian Moral Conservatism," in Contemporary Russian Conservatism: Problems, Paradoxes, and Perspectives, ed. Mikhail Suslov and Dmitry Uzlaner (Leiden: Brill, 2019), 103-27.

18 Clifford Bob calls the outcome of such an emotional struggle "'zombie' policy" (Bob, The Global Right Wing, 6). The materials presented in our publication demonstrate that this trend shows no signs of abating.

Ivan Kurila, Zakliatye druz'ia: Istoriia mnenii, fantazii, kontaktov, vzaimo(ne)ponimaniia Rossii i SShA (Moscow: Novoe literaturnoe obozrenie, 2018).

20 A fake document supposedly discovered by Allied forces in Germany in 1919 and then widely spread in the US by anti-Communists. The first rule is: "Corrupt the young, get them away from religion. Get them interested in sex. Make them superficial. Destroy their ruggedness." A very similar fake document is spreading in post-Soviet Russia under the name of the "Dulles' Plan" (see Vesna Smirnova and Serghei Golunov, "Proliferation of Conspiracy Narratives in Post-Soviet Russia: The 'Dulles' Plan' in Social and Political Discourses," Acta Slavica Iaponica 37 [2016]: 21-45). This plan, supposedly authored by Allen Welsh Dulles, the head of the CIA, includes among other things the following: "Poison the soul of the youth with unbelief in the meaning of life, stimulate interest in sexual issues, attract them with such lures of the free world as discs, poems, songs..." 
itself as a vanguard of emancipation, as a fighter for the progressive transformation of humanity (away from religion and toward atheism ${ }^{21}$ ) and against the reactionary forces of the West, led by obscurantists from the United States. Today positions have changed dramatically - it is the US or the ruling liberal establishment that - in the conservative narrative - has become the new or neo-USSR, spreading subversive ideas about family or the nature of authority around the world, while Russia has become almost a beacon of hope, "the last bastion of Christian values" that helps keep the world from sliding into a new left-liberal dystopia. Russia's self-identity has changed accordingly - now it is Russia who actively resists destructive, revolutionary experiments with fundamental human institutions, experiments inspired by new revolutionary neo-Communists from the United States. Hence the cautious hopes that the US Christian Right have for contemporary Russia: they are literally projecting on Russia as if on a screen their fantasies about another West that has not been infected by the virus of cultural liberalism. ${ }^{22}$

However this vision of Russia finds little support among the Russian voices presented in this volume - with Dugin as a very big exception. These are the voices of Russian intellectuals who are trying to show the deeply problematic nature of the Russian ideology of traditional values and its image as the defender of Christian values. Sergey Chapnin in his contribution shows how new and unusual is this turn to "traditional values" for post-Soviet Russia: as late as the early 2000s traditionalism was still a rather marginal and not particularly elaborated ideology, the basic foundations of which were gradually developed by the future Patriarch Kirill and his circle. Other contributions emphasize how complex and ambiguous the concept of tradition in the Orthodox context is and how crudely this tradition is being instrumentalized for the sake of ideological and geopolitical considerations.

22 Peter Montgomery, "The Religious Right Has an Unholy Crush on Vladimir Putin," Salon, 23 December 2016, https://www.salon.com/2016/12/23/the-religious-right-has-anunholy-crush-on-vladimir-putin_partner/. 
The difference between Russian and American contexts. In interviews, American traditionalists often say that they experience themselves as a kind of new dissident ${ }^{23}$ (hence their interest in the experience of Soviet dissidents), as losers in culture wars, who at any moment could be, if not outlawed, then at least seriously limited in their rights - for example, if discrimination against sexual identity becomes equal to racial or gender discrimination. This understanding of their own desperate situation pushes them to look for hope somewhere else - either in the future, in the hope of some new demographic trend, when conservative religious families have more children than liberal ones, or in exotic cultures and regions - for example, in Russia, which, as I mentioned above, turns into a very convenient screen for all sorts of fantasies about an "alternative West" with an authentic Christian tradition.

The Russian context is strikingly different from the American one. In Russia it is liberals who are nearly dissidents in a society almost totally dominated by conservative actors and institutions. These liberals are in the very vulnerable position of people who could be declared enemies of the people at any time and whose full membership in the national community could easily be questioned. From this experience a completely different attitude to "traditional values" and traditionalism arises, and this attitude is expressed by Russian contributors to this volume: conservatism as a dead ideology, which threatens to turn Russia into a museum of archaic outdated forms, doomed to slowly fading in the face of rapidly developing neighbors both in the West and in the East.

We are "driving on fumes," says Rod Dreher in his interview (p. 33), referring to the decline of American society corrupted by left-liberal ideology. We are "driving on fumes," say Russian liberals, meaning the fading of Russia, which is prevented from any development by the suffocating new ideology of traditionalism.

Focus on Europe. Europe is becoming increasingly important for culture war activists. Against the backdrop of a crisis of mainstream political parties and the rise of right-wing populist movements, in which religion 
and traditional values play an important role, ${ }^{24}$ both Russian and American conservatives look at Europe with hope. The current European situation is perceived as a very good opportunity to open some kind of "second front" in the culture wars. Moreover, some European societies are seen to provide the possibility of a kind of "third way" - compared to overly liberal America and overly authoritarian Russia - and even to redefine the very configuration of culture wars, as Alexander Dugin describes in discussing his "fourth political theory" (p.67). As he puts it, the traditional way of structuring the culture wars was to oppose the union of conservative economic views and conservative social views to the union of progressive economic views and progressive social views. ${ }^{25}$ However, Europe, with its traditions of a social state, can offer a different and more attractive configuration: progressive economic views together with conservative social views versus conservative economic views together with progressive social views. That is, traditional values conservatism could be finally separated from its usual link with the neoliberal economy, which many conservatives reject, and attached to a more progressive economic program.

The fragility of transnational value alliances. Do alliances between Russian and American conservatives have a future? On the one hand, the motivation to build such alliances is strong - both American and Russian actors face the same powerful and insidious enemy. As Rod Dreher says in this regard, referring to one of the key representatives of the Russian Orthodox Church, Metropolitan Hilarion: "the things that divided us in the past, they're important, we can't ignore them completely. But the challenge from post-Christianity and a hostile post-Christian culture is so great that we need to try to help each other" (p. 30). On the other hand, the history of previous conservative alliances show how short-lived these alliances are and how easily circumstances ruin ecumenism 2.0 in its different manifestations. For example, the Vatican, which was one of the first international leaders of the conservative camp, quickly became a great dis-

24 See Nadia Marzouki, Duncan McDonnell, and Olivier Roy, eds., Saving the People: How Populists Hijack Religion (Oxford: Oxford University Press, 2016).

25 See Melinda Cooper, Family Values: Between Neoliberalism and the New Social Conservatism (New York: Zone Books, 2019). 
appointment for the Christian Right: against the backdrop of sexual scandals, the new Pope Francis in 2013 replaced socially conservative rhetoric with a much more moderate stance, open to new progressive social and cultural trends. Another conservative alliance - that between American Evangelicals and Muslim actors (Clifford Bob called it the "Baptist-burqa" network ${ }^{26}$ ) - turned out to be no less fragile: Allan Carlson describes in detail the collapse of this alliance at the moment of the terrorist attack on New York City on 11 September 2001 (p. 38-39).

Actually, disappointment in former allies - Catholic and Muslim was one of the crucial factors that pushed the American Christian Right to seek new allies in Russia. However, given the deterioration of relations between the two countries against the backdrop of the ongoing scandal over possible Russian interference in the US elections in 2016, as well as the instability of the conservative platform in Russia itself, one can assume with some certainty that collaboration between conservatives of the two countries might soon be put to a severe test.

Though some American conservatives are more or less sure that the national culture war is over and that they have lost their battle for the soul of American society, global value conflicts are far from over. And the outcome of this struggle seems open-ended. Global culture wars in the transnational and global dimension have their own logic and their own line of development that may lead to unexpected consequences in different national contexts - including, probably, the American one. So, as one of our interlocutors put it in his interview, "the great battles lie ahead. We'll see how it turns out” (p. 52).

\section{Literature}

Berger, Peter. "Exporting the American Culture War." The American Interest. 20 August 2014, https://www.theamerican-interest.com/2014/08/20/exporting-the-american-culture-war/.

Bob, Clifford. The Global Right Wing and the Clash of World Politics. Cambridge: Cambridge University Press, 2012. Butler, Jennifer. Born Again: The Christian Right Globalized. Ann Arbor, MI: Pluto Press, 2006.

Cooper, Melinda. Family Values: Between Neoliberalism and the New Social Conservatism. New York: Zone Books, 2019.

Bob, The Global Right Wing, 36. 
Dowland, Seth. Family Values and the Rise of the Christian Right. Philadelphia: University of Pennsylvania Press, 2015.

Gathii, James T. “Exporting Culture Wars.” U. C. Davis Journal of International Law \& Policy 13, no. 1 (2006): 67-93. Habermas, Jürgen. “Notes on Post-Secular Society.” New Perspectives Quarterly 25, no. 4 (2008): 17-29.

Himmelfarb, Gertrude. "Comment: The Other Culture War." In Is There a Culture War? A Dialogue on Values and American Public Life, edited by James Davison Hunter and Alan Wolfe, 81. Washington, DC: Pew Research Center, Brookings Institution Press, 2006.

Hunter, James Davison. Before the Shooting Begins: Searching for Democracy in America's Culture War. New York: Free Press, 1994.

Hunter, James Davison. Culture Wars: The Struggle to Control the Family, Art, Education, Law, and Politics in America. New York: Basic Books, 1992.

Kurila, Ivan. Zakliatye druz'ia: Istoriia mnenii, fantazii, kontaktov, vzaimo(ne)ponimaniia Rossii i SShA [Best enemies. The history of opinions, contacts and mutual (mis-) understandings of Russia and the US]. Moscow: Novoe literaturnoe obozrenie, 2018.

Marshall, Katherine. "Engaging on Global Issues in a UN Setting: Religious Actors." In Religion, State and the United Nations: Value Politics, edited by Anna Stensvold, 17-26. New York: Routledge, 2017.

Martel, Frederic. In the Closet of the Vatican: Power, Homosexuality, Hypocrisy. London: Bloomsbury Continuum, 2019.

Marzouki, Nadia, Duncan McDonnell, and Olivier Roy, eds. Saving the People: How Populists Hijack Religion. Oxford: Oxford University Press, 2016.

Montgomery, Peter. "The Religious Right Has an Unholy Crush on Vladimir Putin." Salon. 23 December 2016, https://www.salon.com/2016/12/23/the-religious-right-has-an-unholy-crush-on-vladimir-putin_partner/.

Petersen, Marie Juul, and Heini Skorini. "Hate Speech and Holy Prophets: Tracing the OIC's Strategies to Protect Religion." In Religion, State and the United Nations: Value Politics, edited by Anna Stensvold, 44-61. New York: Routledge, 2017.

Shishkov, Andrey. "Two Ecumenisms: Conservative Christian Alliances as a New Form of Ecumenical Cooperation." State, Religion and Church 4, no. 2 (2017): 58-87.

Smirnova, Vesna, and Serghei Golunov. "Proliferation of Conspiracy Narratives in Post-Soviet Russia: The 'Dulles' Plan' in Social and Political Discourses." Acta Slavica Iaponica 37 (2016): 21-45.

Smolkina, Victoria. A Sacred Space Is Never Empty: A History of Soviet Atheism. Princeton, NJ: Princeton University Press, 2018.

Stoeckl, Kristina. "Postsecular Conflicts and the Global Struggle for Traditional Values" (lecture). State, Religion and Church 3, no. 2 (2016): 102-16.

Suslov, Mikhail. "Russian World" Concept: Post-Soviet Geopolitical Ideology and the Logic of "Spheres of Influence." Geopolitics 23, no. 2 (2018): 330-53.

Uzlaner, Dmitry. "The Logic of Scapegoating in Contemporary Russian Moral Conservatism." In Contemporary Russian Conservatism: Problems, Paradoxes, and Perspectives, edited by Mikhail Suslov and Dmitry Uzlaner, 103-27. Leiden: Brill, 2019. 